\title{
Morality and the Making of Law: Four Questions
}

Timothy Endicott*

Nigel Simmonds' book Law as a Moral Idea is a complex work that repays rereading. ${ }^{1}$ The ideas are not sequenced like beads on a string, but woven into it like threads in a tapestry. I will address a small number of the resulting sophisticated connections among the ideas. The remarks that I have to make are diverse, but I suppose that there is a theme to them: Simmonds is right to call law a 'moral idea', and that implies a connection between law and a moral ideal; in my view, the connection is compatible with a necessary connection between law and the morally non-ideal.

I will respond to Simmonds' ideas by asking four questions. After putting each question I will explain why I ask it, and then I will propose an answer; at some points I know that Simmonds will disagree with my tentative answers, though not perhaps at the most important points.

\section{Is politics a moral idea?}

\section{Why I ask:}

Legal philosophers argue about whether law and morality are conceptually connected, but political philosophers do not argue about whether politics and morality are conceptually connected. The conceptual connection between politics and morality is too obvious. Politics by its very nature is something that ought to be got right, and that can be criticised on moral grounds; that fact about the nature of politics does not mean that there is a general moral value in political decisions. Probably most politicking, along with much of the world's political decision making, is non-ideal.

I am wondering if law, in Simmonds' view, is a moral idea in some further sense, in which the general idea of politics is not. Simmonds describes the idea of law as an archetypal idea ('instantiations of the concept count as such by resemblance or approximation to the archetype') and, moreover, as an aspirational idea (the archetype of law is intrinsically moral, and functions as a 'guiding ideal'). ${ }^{2}$ Is the claim that law is an aspirational idea a very strong, remarkable claim, or a low-key, unobjectionable claim? Like politics, law by its very nature is something that ought to be got right, and that can be criticised on moral grounds. Are they both moral ideas in that sense alone?

\footnotetext{
* $\quad$ Dean of the Faculty of Law, University of Oxford, UK.

$1 \quad$ NE Simmonds, Law as a Moral Idea (Oxford University Press, 2007) (hereinafter LMI).

2 LMI 54. If I understand the idea of an archetype, it might be thought of as a hypothetical paradigm. It is not a particular instance, which we might refer to as a model instance, or point to in making an ostensive definition of a term. It is instead an intellectual construct that we might articulate in giving an explanation of the meaning of a term. I don't make any objection to the idea that some concepts have archetypes in Simmonds' sense. Citing an actual instance of some concept as a paradigm instance (like pointing to it in giving an ostensive definition) might land us in the position of having to explain ourselves if someone asked what makes that instance a paradigm, and then, if I understand it, our response if we had one would be the same as what, in Simmonds' book, is the articulation of an archetype.
} 


\section{A tentative answer:}

Law is self-evidently a moral idea (it is every bit as obvious as Simmonds insists, in spite of the efforts of some legal philosophers to explain law without reference to morality). At least, law is a moral idea in a sense: the same sense in which the idea of politics is a moral idea.

Politics is obviously a moral idea: the affairs of a community may enable the people of the community to live together well, and that is not only a good, but a moral good. I call it a 'moral good' because, unlike some community goods such as fair weather, it is a matter of duty for members of the community to concern themselves with this one. ${ }^{3}$ And the reasons why a member of the community might well be duty-bound to engage in politics are also reasons why a grasp of the idea of politics (unlike a grasp of the idea of astrophysics or even the idea of chess) entails the capacity to make moral judgments.

And yet in another sense, politics is obviously not a moral idea: the fact that some conduct counts as an instance of politics tells us nothing about the morality of the conduct. Even where it would be wrong for a person not to engage in politics, the fact that they are engaging in politics does not even support a presumption that they are doing right. And the fact that such-and-such is the political decision of a person, a group, a political institution, or even a whole political community does not mean that it is even prima facie a morally sound decision.

Politics evidently has a dual aspect. In one respect, the idea of politics is a moral idea; in the second respect it is not. Should we say the same of law as of politics in general? Law-a set of norms that are a particular manifestation of the politics that happen to prevail—has a dual aspect, too.

It is, of course, the idea of the rule of law that distinguishes law from politics in general. Being ruled by law is an instance of being ruled by politics, an instance that involves the goods that are secured when certain aspects of politics are conducted according to general, open, prospective and reasonably clear standards, and when those standards are made and enforced in a way that is ruled by general, open, prospective and reasonably clear standards, and when disputes as to the effect of the standards are resolved by independent tribunals to which people have reasonable access. And, as many have said (even Joseph Raz, whose view of the rule of law is not idealistic enough for Simmonds), those goods are genuine political goods. Certain sorts of political community need those goods, and those communities will be better off if they are ruled by law than if they are ruled by politics that is unconstrained by law. And that is true even though the law has a lot more to answer for than merely for its adherence to the ideal that it, as law, should govern the life of the community. Simmonds rightly points out that this moral ideal ${ }^{4}$ is internally related to the idea of law. So there is something good in the nature of law, because of the value (to certain sorts of political community) in being ruled by law.

$3 \quad$ For present purposes I do not think it necessary to work out the extent to which persons in general have a duty to be involved in politics; it seems to me that there is no general moral duty to serve as a public official or even to vote, although some persons (those whose talents fit them for political service) ought to engage in it, and there is a general duty to participate in politics in certain ways (because, for example, the voluntary payment of a just tax is a political act).

$4 \quad$ Is it an ideal? See John Finnis's contribution to this issue (ref??? ed to add) for an argument that the rule of law is 'best understood not as an ideal or an aspiration but rather as a stringent moral duty or cluster of duties of justice'. I do not think that there is any contradiction between the rule of law 
Does that make law a moral idea in a sense in which politics is not? I am afraid that my answer to this further question is equivocal. Law is still not a moral idea, in roughly the same respect in which politics is not a moral idea: the fact that some conduct conforms to law tells us nothing about the morality of that conduct, except that the conduct takes place in a framework that is free from certain ills that are involved in politics that is not ruled by law, and a framework that has certain positive goods that such politics would lack. It does not tell us that the conduct is right. The law-the prevailing politics of a whole political community, pursued through the form of self-regulation implied by the nature of lawis not even prima facie morally sound; in fact, in its generation by the politics that prevails, it has an inherent proclivity to bias (even in a democracy) in favour of the interests of the powerful. I think this is true even though for some (such as officials bound to abide by the system and forbidden to impose their own sense of justice instead) there is an obligation for the public good to obey the law.

\section{Is there any such thing as law-making?}

\section{Why I ask:}

I ask because of the builder's yard, a metaphor used to introduce one of the central strands of Simmonds' book:

The rules enacted by the powerful ... seem to become law only by their absorption into a system and a body of ideas that transcends the totality of enacted rules. Law seems to be not the builder's yard full of materials but the edifice that results when they are put together in the best way, and that is always an ideal to be achieved rather than a given. ${ }^{5}$

And this strand in the book comes to the fore at a critical juncture, where Simmonds explains the link between the concept of law and the rule of law. This is in fact, as I understand it, the strand in the argument that explains his view that law is an aspirational idea. Simmonds insists on 'the character of law as something that is never fully reducible to a great assemblage of enacted rules, but is always a system awaiting construction from those materials'. ${ }^{6}$ And in the finale, he says that 'law is always an ideal to be constructed, rather than a finite body of materials' ${ }^{7}$

The ‘construction' in Simmonds' theory is not done by law-makers, as I understand him, but by you or by me or by any person who may have cause to ask himself or herself what the law is on a point. And then it seems that no institution of the state ever makes law. Does Simmonds think that there is no such thing as the making of law by exercise of a legal power? If he thinks that there can be such a thing, why does he say that law is 'always awaiting construction' from the materials?

as an ideal and as a duty. To call it an ideal points out, I suppose, that it is never completely attained in its system-wide multiplexity; that fact does not give any of us an excuse for neglecting our duty to adhere to it or to foster it, when justice requires us to do so.

$5 \quad$ LMI 14.

$6 \quad$ LMI 162.

7 LMI 191. 


\section{A tentative answer:}

I think that there is such a thing as law-making, and I think that the idea of law-making (that is, the idea that the law itself may give a person or institution legal power to make the law this rather than that) cannot be reconciled with the idea that law is always an ideal to be constructed.

But as Simmonds points out, it would be a mistake to think that the law of, for example, England in 2010 is merely a set of statutes and decisions. The Hunting Act 2004 provides that 'A person commits an offence if he hunts a wild mammal with a dog ...' (section 1). If I tell you that, and that the Act has not been repealed, you may still need to know a lot more before you can work out how the law treats your participation in field sports. You may need to consider not only the further provisions of the Act—such as the express exemptions—but also:

- $\quad$ the law that gives Parliament the power to make such an enactment, and

- $\quad$ the ways in which statutes are interpreted, and

- the ways in which this statute has been authoritatively interpreted and applied by courts, and

- $\quad$ the law that binds courts to adhere to the authoritatively established ways of applying the Act.

And more. It makes sense to say, as Simmonds says, that enactments such as section 1 of the Hunting Act are part of the 'materials' from which a conclusion as to the law may be constructed.

Incidentally, I think it is a mistake for Simmonds to suggest that HLA Hart would say otherwise. And if that is a mistake, it is hard to see Simmonds' actual disagreement with Hart (although it is very plain that there is actual disagreement). Simmonds says that Hart sought 'to dispel the idea that the existing law is something other than the extant statutes and decisions'. ${ }^{8}$ But Hart could not and did not try to dispel that idea; he endorsed it. In Hart's view, as in any half-decent view, laws are norms, and statutes and other acts of authorities can only be sources of law, and the power-conferring rules of the system determine what law, if any, is made by statutes and other acts of authorities. As Simmonds says, 'the enactment of rules can create law only when the enactment itself was authorized by law'. ${ }^{9}$ Hart would agree, and he would not be making a grudging concession. He insisted on it, and his account of rules of legislation in The Concept of Law was an original and characteristically intelligent (though incomplete) account of the point that Simmonds makes.

We should reject the idea that law is a 'body of materials', but that does not mean that 'law is always an ideal to be constructed'. I have two points in mind:

1. sometimes the law gives a legislature or other agency power to make it the case that the law is (and will be) this rather than that, and

$8 \quad$ LMI 191.

$9 \quad$ LMI 159. 
2. while law involves the determination of its own requirements by its own adjudicative institutions, sometimes those institutions are required by law to treat the materials in one way rather than another.

So, granted that the text of an enactment is part of the 'materials', it seems to me that the law is not 'the edifice that results when they are put together in the best way', but the edifice that the law requires to be constructed. It is one of the ways in which law is reflexive, and here, perhaps, I disagree with the tenor of Simmonds' idealism. If law is an aspirational idea, it is also a self-regulating practice; as a result, law requires the pursuit of its own aspirations, not of yours or mine.

This is actually part of the qualified moral value of law: that it does not leave any legal official to pursue his or her aspirations willy-nilly. Simmonds points out the moral good that lies in the law's regulation of the actions of officials; he finds in it a general protection for independence from the will of others and, if anything, I think he puts too high a value on that aspect of independence. But let's face it, this moral good actually entails a moral limitation of law; law's own aspirations are the aspirations of the ruling powers. That is part of the proclivity to bias that I mentioned above, and it is a necessary connection between law and immorality. It is not a conceptual connection, because it is not hard to conceive of human political authorities that do not act unfairly in the interests of the powerful (and there have actually been instances of just laws!). But if a community is governed in general ways by human beings in positions of political power, it is necessarily governed in a way that lends itself to this bias. The law requires the construction of an edifice that suits the powerful.

But in doing so, I think that the law very often allows different edifices to be constructed; which brings us to Question 3.

\section{Is there a right answer to every legal dispute?}

\section{Why I ask:}

It is a question that tests Simmonds' account of the rule of law, and of its value. The prospectivity of law is a very important feature in that account, because Simmonds uses it in his argument that the rule of law gives us a form of independence from the will of others. He suggests that if judges had wideranging legal power to alter the law, even interstitially, 'the rule-as-modified' would be 'applied in the very case that gave rise to the modification, so that all such cases would have to be regarded as the most serious departures from the rule of law'.10

A judicial decision applying a vague law in a borderline case would (if the vagueness of the law gives the court a discretion to decide the case either way) count as applying a rule-as-modified in the very case that gives rise to the modification. So I ask: if there is not a right answer, according to law, to every legal dispute, how can the resultant discretion of judges be reconciled with the rule of law? But, even on Simmonds' account of law as an edifice that results when the materials are put together in the best way, how can there be a single right answer to every dispute that a court must resolve? 


\section{A tentative answer:}

Remember the builder's yard: we must do something with the materials, and we cannot just say that the law is the materials. But there is no reason to think that our principles for dealing with the materials will answer all the questions to which the community’s affairs require an answer.

Moral considerations do not eliminate indeterminacy in the law; they compound it. The provision against hunting a wild mammal with a dog is vague, not least because (even when it is clear that this animal is a wild mammal and that animal is a dog) there is no sharp boundary to the category of actions (in relation to this wild mammal and that dog) that would count as hunting the mammal with the dog. Now, a good judge won't simply respond to the vagueness of the Act with a shrug, and flip a coin as soon as there are plausible arguments either way. In deciding how, according to law, the category is to be determined, a decent judge will attend both to the moral principles (relating to protection of wild animals from cruelty) behind the legislative measure, and also to moral principles (such as the principle of liberty) which might be in tension with the aims of the measure, and which Parliament presumably did not merely renounce by passing the Act. It would, though, be a basic mistake to think that those extremely vague principles will determine a single right answer to every conceivable question as to whether a person prosecuted under the Act can lawfully be convicted of hunting a particular wild mammal with a particular dog.

If judges are bound to appeal to moral principles to resolve an uncertainty in the materials, it is all the more obvious that the law gives them discretion; in fact, the rightness of appealing to moral principles in an uncertain case makes the creation of uncertainty in sources of law into a potentially useful technique for allocating creative legal power to judges. And when judges accept (as they often ought to accept) an equitable jurisdiction to dispense with legal obligations or to decline to give effect to legal rights on the ground of conscience, they compound their discretion. These important and far-reaching forms of discretion are not necessarily contrary to the rule of law, because governance of a community cannot be pursued at all if we refuse to use vague laws, ${ }^{11}$ and it cannot be done well without the forms of vagueness (in, for example, the equitable powers of courts) that generate substantial judicial discretion.

We need an understanding of arbitrary government if we are to understand the rule of law. The rule of law is opposed to arbitrary government (just as it is opposed to anarchy). But it is not opposed to judicial discretion in general; we need an understanding of arbitrary government that does not make the basic mistake of classifying all legally uncontrolled judicial decision-making as arbitrary in the sense that is relevant to the rule of law. A good account of arbitrary government will explain why legitimate judicial action may call for a justification other than the conjunction of (1) the fact that a dispute needs to be resolved and (2) the fact that after a fair process the judge is deciding in good faith, on grounds that are compatible with the legal materials. For both (1) and (2) may be the case when a court

11 For an argument to this effect, see T Endicott, 'Law is Necessarily Vague' (2001) 7 Legal Theory 377-83. 
exercises legal discretion. The resulting account of the limits of legitimate judicial discretion would be a necessary element in a complete explanation of the rule of law. ${ }^{12}$

\section{What justifies a judicial decision?}

\section{Why I ask:}

This question is important for understanding Simmonds' account of the nature of law, and its relation to just adjudication. One of the brilliant insights of the book is this:

... law is invoked by judges as a justification for their decisions, and judges could not intelligibly invoke the mere fact of their acceptance of a rule (for what might be wholly selfregarding reasons) as a justification for their decision. ${ }^{13}$

I think that is right. What is the alternative to justifying a decision by invoking the mere fact of acceptance? Simmonds suggests the following:

Perhaps the judicial task is one of fidelity, not to a rule of recognition, but to the idea of law itself ... ${ }^{14}$

But I do not think that judges can intelligibly invoke faithfulness to the idea of law itself as a justification for their decisions, either.

I wonder if it is liberty as independence that makes Simmonds appeal to the idea of law itself. That is, the book seems to support the notion that judges can and must appeal to the idea of law, because only then will you and I be independent of the will both of the judges themselves, and of whatever institutions took decisions that the judges must treat as material for their decision. You can see how this puzzle is connected to the puzzle I raised earlier regarding the builder’s yard. Both in the builders' yard strand of the book and in the strand concerning the justification of adjudicative decisions, Simmonds seems to suggest that you and I can never legitimately be subject to authority.

\section{A tentative answer:}

An adjudicative decision is not justified merely by the fact that it conforms to a pattern of practice by other judges (this is an instance of the principle that acting in conformity with a customary rule is not justified by the mere fact of concurrent behaviour). But then, fidelity to the idea of law does not justify an adjudicative decision, either. It is fidelity to the law (not to the idea of law) that justifies a decision. And fidelity to the law provides a justification only in the same incomplete and presumptive fashion in

12 For some elements in such an account of arbitrary government, see T Endicott, Administrative Law (Oxford University Press, 2009) 4-9.

$13 \quad$ LMI 159.

$14 \quad$ LMI 157. 
which, for example, a babysitter can justify her decision to send a child to bed at 9 pm by explaining that the parents said that $9 \mathrm{pm}$ is bedtime. The justification is incomplete because it assumes an explanation of why the children and the babysitter ought to go along with the say-so of the parents. It is presumptive because an astute child may be able to point out considerations that were not present in the minds of the parents when they said that $9 \mathrm{pm}$ is bedtime.

In the case of the babysitter, the idea of parental authority does not justify a decision to send the children to bed at the time the parents said. The parents' authority justifies it. In the case of legal adjudication, the idea of law does not justify a decision. The justification is the authority of particular institutions, and, in particular, the authority given to political institutions by the legal system's techniques for identifying law-making acts. The potential justifications for an adjudicative decision pertain to the particular system, and may admit of no general description even for a single particular system. Although adjudication is simpler than some forms of political decision making (because authorities can bind a court), this point unifies adjudication with the rest of politics: the justifications for a decision may be plural and diverse, and may admit of no general description.

But we can say this in general: law authorises human institutions to make general rules, and human institutions cannot provide general rules that will turn out to be well adapted to all eventualities even when the people in the institutions are good-hearted and wise, and are able to resist the proclivity to bias. As a result, I believe that it is a truth, in every human community with a legal system, that the law (and I mean the law, and not just the materials in the builder's yard) is not ideal. 